\section{Profitability of Sensor-based Irrigation in Greenhouse and Nursery Crops}

\author{
Erik Lichtenberg ${ }^{1,3}$, John Majsztrik $^{2}$, and Monica Saavoss ${ }^{1}$
}

\begin{abstract}
AdDitional INDEX wORDs. economics, disease management, gardenia production, precision irrigation, production time management, sensor technology, wireless sensor networks

SUMMARY. Improvements in sensor technology coupled with advances in knowledge about plant physiology have made it feasible to use real-time substrate volumetric water content sensors to accurately determine irrigation timing and application rates in soilless substrates in greenhouse and container production environments. Sensor-based irrigation uses up-front investments in equipment and system calibration in return for subsequent reductions in irrigation water use and associated costs of energy and labor, spending on fertilizer, and disease losses. It can also accelerate production time. We present formulas for assessing profitability when benefits and costs are separated in time and apply those formulas using data from an experiment on production of gardenia [ Gardenia augusta 'MADGA 1' (Heaven Scent ${ }^{\mathrm{TM}}$ )]. Sensor-controlled irrigation cuts production time and crop losses by more than half. Annualized profit under the wireless sensor system was over $\mathbf{1 . 5}$ more than under the nursery's standard practice, with the bulk of the increase in profit due to the reduction in production time. These results indicate that controlling irrigation using wireless sensor systems is likely to increase profitability substantially, even if efficiency gains are not as high as those achieved under experimental conditions.
\end{abstract}

$\mathrm{I}$ mprovements in sensor technology coupled with advances in knowledge about plant physiology have made it feasible to use real-time substrate volumetric water content sensors to accurately determine irrigation timing and application rates in soilless substrates in greenhouse and container production environments (Belayneh et al., 2013; Burnett and van Iersel, 2008; Lea-Cox et al., 2010). Wireless transmission of sensor data allows for real-time management of the irrigation system. Wireless sensor-based irrigation management offers significant potential benefits to greenhouse operators (Nemali et al., 2007; Scoggins and van Iersel, 2006). By matching water applications with moisture availability and plant uptake rates, sensor-based irrigation can reduce irrigation water use without risking adverse consequences from under- or

This paper is part of a series of manuscripts describing the research and development completed by the SCRI-MINDS (Managing Irrigation and Nutrition through Distributed Sensing) project. The authors gratefully acknowledge funding and support from the USDA-NIFA Specialty Crops Research Initiative; Award \#2009-51181-05768.

${ }^{1}$ Department of Agricultural and Resource Economics, 2102 Symons Hall, University of Maryland, College Park, MD 20742

${ }^{2}$ Department of Plant Science and Landscape Architecture, 2102 Plant Science Building, University of Maryland, College Park, MD 20742

${ }^{3}$ Corresponding author. E-mail: elichten@umd.edu. overwatering. Better matching of moisture availability with plant demands can also reduce leaching of nutrients, resulting in fertilizer savings as well as water savings. In the many watersheds where runoff of nutrients causes eutrophication, reductions in nutrient leaching can benefit the environment as well as contribute to growers' bottom lines (Majsztrik et al., 2013). Wireless soil moisture sensor systems provide more accurate measurements of substrate moisture status than qualitative methods (weight, appearance, length between irrigation cycles, etc.) and require less labor (Lea-Cox et al., 2010; Majsztrik et al., 2011; Nemali and van Iersel, 2006; van Iersel et al., 2009).

Savings in irrigation water, labor, energy, and fertilizer expenditures are obvious potential benefits of soil moisture sensor systems. Other potential benefits of sensor systems are less obvious. Greater precision in maintaining soil moisture at desired levels can lower disease pressure, often caused by precautionary overwatering (Chappell et al., 2012). Lower disease pressure means reduced crop losses in addition to less fungicide use. Better matching of water availability to plant uptake has also been shown to accelerate growth in some instances (Chappell et al., 2013). Shorter production times mean higher profits, just as lower costs do.

Achieving these potential benefits requires installation and calibration of equipment and software (Kohanbash et al., 2013). In essence, sensor-based irrigation systems substitute capital for water and associated variable inputs such as energy, labor, and fertilizer (Shani et al., 2009). The profitability of investing in wireless sensor systems thus depends on the relative magnitudes of benefits and costs. Those benefits and costs are incurred at different times: Investment in sensor systems is made up front, while reductions in spending on water, energy, labor, fertilizer, and pesticides accrue later on, as do any benefits from shortening production time or reducing disease losses. This paper presents a methodology for calculating the profitability of investing in sensor-based irrigation management that takes these differences in timing into account. It then applies that methodology to data from gardenia production in a Georgia nursery as part of a project focused on implementation of wireless irrigation sensor networks for ornamental plant production.

\section{Materials and methods}

When benefits and costs accrue at different points in time, calculating profit - or, indeed, comparing them in any way-requires putting benefits and costs on a common time footing. The most convenient method is converting all revenues and costs to constant periodic payments; e.g., annualizing them. We begin by discounting all revenues and costs to convert them to their present values. We then calculate the present value of profit, which we convert to a constant annual payment (or loss). Finally, we calculate profit (or loss) per unit area to permit scaling up or down.

\begin{tabular}{llll}
\hline $\begin{array}{l}\text { Units } \\
\text { To convert U.S. to SI, } \\
\text { multiply by }\end{array}$ & U.S. unit & SI unit & $\begin{array}{l}\text { To convert SI to U.S., } \\
\text { multiply by }\end{array}$ \\
\hline 0.0929 & $\mathrm{ft}^{2}$ & $\mathrm{~m}^{2}$ & 10.7639 \\
0.0283 & $\mathrm{ft}^{3}$ & $\mathrm{~m}^{3}$ & 35.3147 \\
3.7854 & gal & $\mathrm{L}$ & 0.2642
\end{tabular}


Formally, let $q_{i t}$ denote the quantity sold at time (year, month, week) $t$ using production system $i, p_{t}$ the unit price of the crop received at time $t$ and $e_{i j t}$ expenditures on input $j$ at time $t$, where $i=\{s, n\}$ denotes a sensor-based or non-sensor-based system. Net profit (or loss) earned at time $t$ using the sensor-based system is $p_{t} q_{s t}-\sum_{j} e_{s j t}$. The present value of net profit (or loss) earned at time $t$ using the sensor-based system is $\frac{p_{t} q_{s t}-\sum_{j} e_{s j t}}{(1+r)^{t}}$, where $r$ is the periodic interest rate. The present value of net profit (or loss) earned at time $t$ using the non-sensor-based system is $\frac{p_{t} q_{n t}-\sum_{j} e_{n j t}}{(1+r)^{t}}$.

Let $K$ denote the initial investment cost of the sensor-based system, $f_{t}$ the sensor equipment expenditures at time $t, C_{s}$ and $C_{n}$ the crop production costs at planting incurred under the sensor-based and non-sensorbased systems, and $T_{s}$ and $T_{n}$ the respective times until the end of the production cycle under the sensorbased and non-sensor-based systems. The present value of profit earned over the entire production cycle under the sensor-based system is $V_{s}=\sum_{0}^{T_{s}} \frac{p_{t} q_{s t}-f_{t}-\sum_{1}^{J} e_{s j t}}{(1+r)^{t}}-C_{s}-K$. The present value of profit earned over the entire production cycle under the non-sensor-based system is $V_{n}=\sum_{0}^{T_{n}} \frac{p_{t} q_{n t}-\sum_{1}^{J} e_{n j t}}{(1+r)^{t}}-C_{n}$.

Annualization of profit may require adjustments in time period accounting. For many nursery operations, it makes sense to account for revenues and costs on a less-than-yearly basis; e.g., monthly or weekly. In such cases, the periodic interest rate $r$ is not an annual interest rate. If revenues and costs are tracked monthly or weekly, then the respective monthly and weekly interest rates are $1 / 12$ and $1 / 52$ of the annual interest rate; i.e., $i=12 r$ or $i=52 r$. Similar adjustments may be needed for time of production. If revenues and costs are tracked monthly, the production period on a yearly basis is $A=T / 12$; if revenues and costs are tracked on a weekly basis, the production period on a yearly basis is $A=T / 52$.
Annualized profit under the sensorbased system is then $Z_{s}=\frac{i V_{s}}{1-\frac{1}{(1+i)^{A_{s}}}}$

while annualized profit under the non-sensor-based system is $Z_{n}=$ $\frac{i V_{n}}{1-\frac{1}{(1+i)^{A_{n}}}}$. The annualized cost of the sensor system is $k=$ $\frac{i\left[K+\sum_{t=0}^{T_{s}} f_{t}\right]}{1-\frac{1}{(1+i)^{A_{s}}}}$.

The change in annualized profit from switching to the sensor-based system from the non-sensor-based system is $Z_{s}-Z_{n}$. The annual rate of return on capital invested in the sensor-based system is $\frac{Z_{s}-Z_{n}}{k}$. The payback period, expressed in years, is the inverse of the annual rate of return, $\frac{k}{Z_{s}-Z_{n}}$.

We use this procedure in a case study of the likely profitability of investing in a wireless sensor system for scheduling irrigation in greenhouse production of 'MADGA l' gardenias (Heaven Scent ${ }^{\mathrm{TM}}$ ). Estimates of the effects of using a wireless sensor system were taken from experimental data. A characterization of production activities and estimates of sales and costs incurred with and without the wireless sensor system was obtained from the grower cooperating in the experiment.

The experiment involved using a wireless network to monitor environmental conditions and control substrate water content of 1 -gal gardenias in 10 bays covering $20,000 \mathrm{ft}^{2}$ in an unheated greenhouse at a large commercial nursery in Dearing, GA. Liners were planted into 1 -gal containers filled with a bark-based substrate in June 2010 , with each bay containing 2340 gardenias. An irrigation controller (Moisture Clik IL200-MC; Dynamax, Houston, TX) that uses a dielectric soil moisture sensor (SM200; Dyna$\max )$ to measure substrate water content was used to control irrigation. These controllers use a single soil moisture probe, which was placed in a container centrally located within each block of plants to avoid edge effects. Irrigation application was triggered when substrate water content dropped below $0.20 \mathrm{~m}^{3} \cdot \mathrm{m}^{-3}$. A 24 -h timer was used to power off the Moisture Clik controllers between 1700 and $0800 \mathrm{HR}$ to prevent irrigation at night. A water meter attached to each bay was used to monitor water use. Irrigation volumes were recorded monthly. Other than irrigation, production followed the standard cultural practices of the nursery (Chappell et al., 2013). All plants were harvested by the end of May 2011. Changes in time of production were estimated by comparing actual sales of the experimental crop with sales from the nursery's historical record.

Nursery personnel controlled irrigation in the remaining five bays of the greenhouse, and were told to irrigate according to their regular practices. A previous experiment at the same nursery showed that water use could be reduced by over $80 \%$ with no adverse effects on production (van Iersel et al., 2009). Perhaps inspired by that experiment, nursery personnel ignored instructions and used the water meters to match the irrigation volume applied by the sensors in the five bays they were controlling. As a result, the experiment was unable to determine changes in water use due to the wireless sensor system. Thus, instead of comparing experimental and control plants in the same greenhouse, production in the experimental greenhouse was compared with the operation's typical production practices, outcomes, and costs for this gardenia cultivar. Gardenia production elsewhere in the nursery under the nursery's standard practice during the experimental period conformed to the historic pattern of maturation, losses, and sales, indicating that this comparison is valid. The comparison data were provided by the cooperating grower, who keeps a detailed accounting of per-plant variable costs for business management purposes. Water use was not included in the grower's accounting, so we were unable to determine changes in water use under the wireless sensor system by comparing water use in the experiment with historical water use.

Although the experiment was unable to examine changes in water use, it did find substantial changes in time of production. Actual sales of the experimental crop were compared with sales from the nursery's historical record (Fig. 1). Plants grown with sensor-controlled irrigation were first ready for sale by February of the following year, 8 months after planting, and all were sold by the end of the 


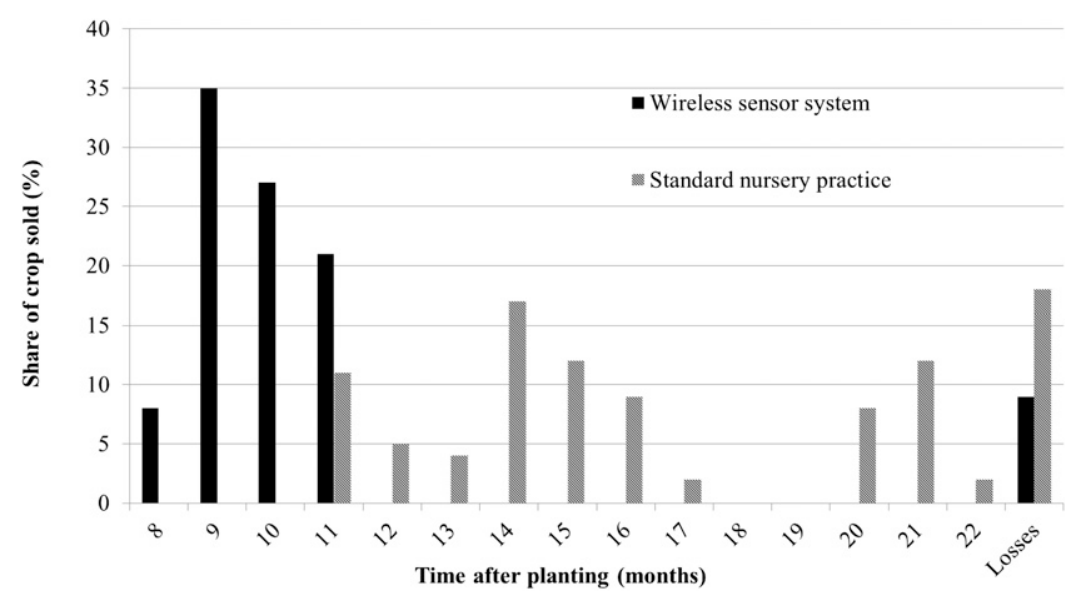

Fig. 1. Temporal distribution of sales and losses comparing a wireless irrigation sensor system and standard nursery practice for production of gardenias in an unheated greenhouse in Dearing, GA.

spring planting season, 11 months after planting. In contrast, historical sales records indicate that the first plants were typically ready for sale by May of the following year ( 11 months after planting), missing much of the spring planting season. Sales were usually slow during the summer, then picked up during August through the beginning of November. The plants were then overwintered until February of the next year. The full crop was thus completely sold by the beginning of May, almost 2 years after planting. Thus, under the experimental regime, sales were completed during the same month that plants had historically first been ready for sale and the sale of all plants in the crop was completed in half the time needed historically. The sales-weighted average time to sale of the experimental crop was 9.7 months, $36 \%$ below the sales-weighted average historic time to sale of 15.2 months.

The experiment also found substantial changes in crop losses. Historically, $18.2 \%$ of plants planted died or could not be sold (Fig. 1). The experimental regime cut those losses in half, mainly by eliminating losses due to disease (Chappell et al., 2013).

Production practices and their associated costs were obtained from the nursery operator. Liners cost $\$ 0.50$ each. Pots, substrate, fertilizer, planting labor, and herbicide treatment cost $\$ 0.7467$ per plant. Monthly labor, overhead, and other costs amounted to $\$ 0.0568$ per plant. Plants received a foliar fungicide treatment every 2 weeks from April through October at a total cost of $\$ 0.025$ per plant. Under the standard production regime, each plant received a fungicide drench every 6 months at a cost of $\$ 0.045$ per plant. Use of the wireless sensor system eliminated the need for (and cost of) this fungicide drench. Finally, each plant received a top dress of fertilizer after 12 months. Because all plants produced under the experimental regime were sold by the end of 11 months, use of the wireless sensor system eliminated this cost as well.

Crop losses were assumed to occur at a constant monthly rate during the entire time plants were present in the nursery, beginning 6 months after planting and continuing until all remaining plants were sold. The cooperating grower confirmed that this assumption was reasonable. Plants sold were valued at the nursery's wholesale price of $\$ 6.50$ each.

Revenue, expenditures, and profit were calculated on a monthly basis discounted at an interest rate of $6 \%$ (or $0.5 \%$ per month), roughly the average interest rate paid by small businesses reported by the National Federation of Independent Businesses as of Dec. 2012 (Dunkelberg and Wade, 2013). Interest was compounded continuously. The present values of revenue, cost, and profit under the experimental and historic systems were obtained by adding up discounted monthly revenue, expenditures, and profit over the entire production cycle. Those present values were then annualized using the same $6 \%$ annual rate assuming a production cycle lasting 11 months under the experimental system and 22 months historically. By putting all revenues and costs on an equal time footing, annualization avoids the need to account explicitly for the differential cost of greenhouse space occupied by the crop under historic production procedures, but freed up under the experimental sensor-based system.

The wireless sensor system consisted of 40 sensors (10HS; Decagon Devices, Pullman, WA) costing $\$ 70$ apiece, connected to eight nodes (Decagon nR5 nodes) costing $\$ 675$ each, which transmitted the sensor data to a single base station costing $\$ 60$. Other electrical supplies used were estimated to cost $\$ 1000$. The data were processed using software whose license was estimated to cost $\$ 450$. The computer used to run the software and view the data was estimated to cost $\$ 600$. The entire system was annualized over a 3-year lifetime, a very conservative assumption that likely overstates the true yearly cost.

\section{Results and discussion}

Investment in the wireless sensor system increased the overall presentvalue cost of production by $3.6 \%$ over standard practice at this nursery (Table 1). The present value of revenue under the wireless sensor system was $12.8 \%$ higher than under the nursery's standard practice, in part because reductions in disease losses increased the total number of plants harvested by $11.1 \%$ and in part because sales started and ended much earlier. Because more plants were harvested, the production cost per plant was $6.7 \%$ lower with the wireless sensor system than under the standard practice. As a result, profit was $20.6 \%$ higher with the wireless sensor system than under the nursery's standard practice.

This difference in profit understates the actual increase in profit due to use of the wireless sensor system. Shortening the production cycle frees up greenhouse space for planting another crop. The production statistics in Fig. 1 indicate that using the wireless sensor system comes close to doubling the number of plants that can be grown in the 22 months needed to finish out a single crop under the nursery's standard practice. Annualizing revenue, expenditures, and profit takes this timing difference into account, as noted earlier, avoiding the need for an explicit accounting of the cost of greenhouse space. On an annual basis, revenue was 119\% higher under the wireless sensor system than 
Table 1. Monthly accounting of present-value expenditures, sales, revenues, and profits for the production of gardenias at a greenhouse operation in Dearing, GA.

\begin{tabular}{|c|c|c|c|c|c|c|c|c|c|}
\hline \multirow[b]{2}{*}{ Month } & \multirow[b]{2}{*}{$\begin{array}{c}\text { Time after } \\
\text { planting (mo.) }\end{array}$} & \multicolumn{4}{|c|}{ Standard practice } & \multicolumn{4}{|c|}{ Sensor-based irrigation } \\
\hline & & $\begin{array}{c}\text { Expenditure } \\
(\$)\end{array}$ & $\begin{array}{c}\text { Quantity } \\
\text { sold }\end{array}$ & $\begin{array}{c}\text { Revenue } \\
(\$)\end{array}$ & $\begin{array}{c}\text { Profit } \\
(\$)\end{array}$ & $\begin{array}{c}\text { Expenditure } \\
(\$)\end{array}$ & $\begin{array}{c}\text { Quantity } \\
\text { sold }\end{array}$ & $\begin{array}{c}\text { Revenue } \\
(\$)\end{array}$ & $\begin{array}{c}\text { Profit } \\
(\$)\end{array}$ \\
\hline June & 0 & 29,173 & & & & 39,483 & & & \\
\hline July & 1 & 1,439 & & & $-1,439$ & 1,439 & & & $-1,439$ \\
\hline August & 2 & 1,432 & & & $-1,432$ & 1,432 & & & $-1,432$ \\
\hline September & 3 & 1,425 & & & $-1,425$ & 1,425 & & & $-1,425$ \\
\hline December & 6 & 2,287 & & & $-2,287$ & 2,277 & & & $-2,277$ \\
\hline January & 7 & 1,256 & & & $-1,256$ & 1,245 & & & $-1,245$ \\
\hline February & 8 & 1,236 & & & $-1,236$ & 1,219 & 1,861 & 11,449 & 10,230 \\
\hline March & 9 & 1,216 & & & $-1,216$ & 1,194 & 8,190 & 50,135 & 48,941 \\
\hline April & 10 & 1,302 & & & $-1,302$ & 1,271 & 6,222 & 37,898 & 36,626 \\
\hline May & 11 & 1,281 & 2,499 & 15,374 & 14,093 & 1,244 & 4,999 & 30,297 & 29,052 \\
\hline September & 15 & 696 & 2,819 & 17,000 & 16,303 & 0 & & 0 & 0 \\
\hline October & 16 & 518 & 2,127 & 12,763 & 12,245 & 0 & & 0 & 0 \\
\hline November & 17 & 349 & 372 & 2,221 & 1,872 & 0 & & 0 & 0 \\
\hline December & 18 & 565 & 0 & 0 & -565 & 0 & & 0 & 0 \\
\hline January & 19 & 301 & 0 & 0 & -301 & 0 & & 0 & 0 \\
\hline February & 20 & 287 & 1,819 & 10,698 & 10,412 & 0 & & 0 & 0 \\
\hline March & 21 & 179 & 2,872 & 16,807 & 16,628 & 0 & & 0 & 0 \\
\hline April & 22 & 21 & 383 & 2,230 & 2,209 & 0 & & 0 & 0 \\
\hline Total & & 53,019 & 19,145 & 115,099 & 62,080 & 54,941 & 21,272 & 129,779 & 74,837 \\
\hline
\end{tabular}

Table 2. Annualized revenue, expenditures, and profit: wireless sensor system versus standard practice, based on greenhouse production of gardenias for an operation in Dearing, GA.

\begin{tabular}{|c|c|c|c|c|}
\hline & $\begin{array}{c}\text { Standard } \\
\text { practice }(\$)\end{array}$ & $\begin{array}{l}\text { Sensor-based } \\
\text { irrigation }(\$) \\
\end{array}$ & $\begin{array}{c}\text { Sensor-based irrigation, } \\
\text { shorter production } \\
\text { time only }(\$)\end{array}$ & $\begin{array}{c}\text { Sensor-based irrigation, } \\
\text { no losses only }(\$)\end{array}$ \\
\hline Annualized production expenditures & $30,539.11$ & $50,039.93$ & $49,995.21$ & $30,926.04$ \\
\hline Annualized sensor system cost & & $3,755.24$ & $3,755.24$ & $3,755.24$ \\
\hline Annualized profit & $35,758.24$ & $91,710.47$ & $77,206.01$ & $38,985.23$ \\
\hline $\begin{array}{l}\text { Annualized sensor system cost } \\
\text { per square foot }\end{array}$ & & 0.19 & 0.19 & 0.19 \\
\hline Annualized profit per square foot & 1.79 & 4.59 & 3.86 & 1.95 \\
\hline
\end{tabular}

${ }^{\mathrm{z}} \$ 1.00 / \mathrm{ft}^{2}=\$ 10.7639 / \mathrm{m}^{2}$.

under the nursery's standard practice (Table 2). Annual expenditures on production (net of sensor system costs) were $64 \%$ higher under the wireless sensor system than under the nursery's standard practice. Adding annualized sensor system costs brings production costs using the wireless sensor system to $76 \%$ over production costs compared with the nursery's standard practice. The percentage difference in profit is a weighted sum of percentage differences in revenue and cost, where the percentage difference in revenue is weighted by the ratio of revenue to profit and the percentage difference in cost is weighted by the ratio of cost to profit. Revenue under the industry's standard practice was $185 \%$ of profit while cost was $85 \%$ of profit, so that annual profit was $156 \%$ higher under the wireless sensor system than under the nursery's standard practice. The payback period for investment in the wireless sensor system was less than 1 month (although payback is not realized until plants are sold, beginning 8 months after planting).
Not surprisingly, the increase in profitability due to the use of the wireless sensor system was not sensitive to the choice of a $6 \%$ interest rate. In fact, the increase in annualized profit was slightly higher at higher interest rates: At an interest rate of $10 \%$, the increase in annualized profit was $157 \%$ while at an interest rate of $20 \%$ the increase in annualized profit was $161 \%$. A higher interest rate has two opposing effects on the difference in annualized profit. On the one hand, it increases the annualized cost of investing in a wireless 
sensor system. On the other hand, it reduces the present value of revenue under the nursery's standard irrigation practice. These two opposing effects come close to cancelling each other out at reasonable interest rates.

Use of the wireless sensor system increases profitability in two ways: by accelerating production and by reducing losses. We conducted a sensitivity analysis to estimate the extent to which the overall increase in profit could be attributed to each. To estimate the extent to which the increase in profit was due to accelerating the production cycle, we calculated annualized revenue, expenditures, and profit assuming the shorter production time experienced under the wireless sensor system but kept disease losses at the level experienced under the nursery's standard practice. To estimate the extent to which the increase in profit was due to reductions in losses, we calculated annualized revenue, expenditures, and profit assuming losses experienced under the wireless sensor system but kept the temporal distribution of sales at the level experienced under the nursery's standard practice.

Reducing production time was responsible for the most of the increase in profit (Table 2). Annual revenue in the reduced production time scenario was almost double than that under the nursery's standard practice, whereas annual production expenses net of sensor system costs remained 64\% higher. As a result, annual profit was $116 \%$ higher in this scenario than that under the nursery's standard practice.

Reducing losses had a much smaller impact on profit (Table 2). Annual revenue in the reduced losses scenario was only $11 \%$ higher than that under the nursery's standard practice while annual production expenditures (net of sensor system costs) were almost the same. As a result, annual profit was only $9 \%$ higher in this scenario than under the nursery's standard practice. Accelerated production time and reduced losses taken separately account for a $125 \%$ increase in profit. The remaining $31 \%$ increase in profit is due to the combination of the two.

\section{Conclusion}

Sensor-based irrigation management can reduce irrigation water use and associated costs of energy and labor, spending on fertilizer (and leaching of excess nutrients), and disease losses. It can also accelerate production time. In essence, sensor-based irrigation substitutes capital for variable inputs, trading off up-front investment in equipment and system calibration, for benefits such as reduced input use, reductions in losses, and acceleration of production that accrue later on.

We present formulas for assessing profitability when benefits and costs are separated in time and apply those formulas using data from an experiment on gardenia production. Controlling irrigation using data from moisture sensors led to substantial reductions in both production time and crop losses: The weighted average time from planting to sale was over one-third lower while crop losses were reduced by $50 \%$. Annualized profit under the wireless sensor system was over 1.5 times more than under the nursery's standard practice, with the bulk of the increase in profit due to the reduction in production time. These results indicate that controlling irrigation using wireless sensor systems is likely to increase profitability substantially, even if efficiency gains are not as high as those achieved in this experiment.

Using wireless sensor systems can have environmental as well as private economic benefits (see Majsztrik et al., 2013). More efficient water use can reduce pressure on increasingly scarce water supplies. More efficient energy use can reduce carbon emissions, and more efficient fertilizer use can lower runoff and thus nutrient pollution of waterways. The design and conduct of the experiments used in our analysis prevented us from estimating these potential benefits to society at large, but this technology clearly has promise as a win-win combination of economic and environmental improvements.

\section{Literature cited}

Belayneh, B.E., J.D. Lea-Cox, and E. Lichtenberg. 2013. Costs and benefits of implementing sensor-controlled irrigation in a commercial pot-in-pot container nursery. HortTechnology 23:760-769.

Burnett, S.E. and M.W. van Iersel. 2008. Morphology and irrigation efficiency of Gaura lindheimeri grown with capacitance sensor-controlled irrigation. HortScience 43:1555-1560.

Chappell, M., S.K. Dove, M.W. van Iersel, P.A. Thomas, and J. Ruter. 2013. Implementation of wireless sensor networks for irrigation control in three container nurseries. HortTechnology 23:747-753.
Chappell, M., M. van Iersel, E. Lichtenberg, J. Majsztrik, P. Thomas, J. Ruter, and S. Wells. 2012. Benefits of Precision Irrigation of Gardenia augusta "Heaven Scent"TM: Reducing Shrinkage, Shortening the Cropping Cycle, and Economic Impact. Proc. Southern Nursery Assn. Res. Conf. 57:321-323.

Dunkelberg, W.C. and H. Wade. 2013. National Federation of Independent Business: Small business economic trends, January 2013. Natl. Federation Independent Business, Nashville, TN.

Kohanbash, D., G. Kantor, T. Martin, and L. Crawford. 2013. Wireless sensor network design for monitoring and irrigation control: User-centric hardware and software development. HortTechnology 23:725-734.

Lea-Cox, J.D., G.F. Kantor, W.L. Bauerle, M.W. van Iersel, C. Campbell, T.L. Bauerle, D.S. Ross, A.G. Ristvey, D. Parker, D. King, R. Bauer, S.M. Cohan, P. Thomas, J.M. Ruter, M. Chappell, M. Lefsky, S. Kampf, and L. Bissey. 2010. A Specialty Crops Research Project: Using Wireless Sensor Networks and Crop Modeling for Precision Irrigation and Nutrient Management in Nursery, Greenhouse and Green Roof Systems. Proc. Southern Nursery Assn. Res. Conf. 55:211-215.

Majsztrik, J.C., A.G. Ristvey, and J.D. Lea-Cox. 2011. Water and nutrient management in the production of containergrown ornamentals. Hort. Rev. 38:253-297.

Majsztrik, J.C., E.W. Price, and D.M. King. 2013. Environmental benefits of wireless sensor-based irrigation networks: Casestudy projections and potential adoption rates. HortTechnology 23:783-793.

Nemali, K.S., F. Montesano, S.K. Dove, and M.W. van Iersel. 2007. Calibration and performance of moisture sensors in soilless substrates: ECH2O and Theta probes. Sci. Hort. 112:227-234.

Nemali, K.S. and M.W. van Iersel. 2006. An automated system for controlling drought stress and irrigation in potted plants. Sci. Hort. 110:292-297.

Scoggins, H.L. and M.W. van Iersel. 2006. In situ probes for measurement of electrical conductivity of soilless substrates: Effects of temperature and substrate moisture content. HortScience 41:210-214.

Shani, U., Y. Tsur, A. Zemel, and D. Zilberman. 2009. Irrigation production functions with water-capital substitution. Agr. Econ. 40:55-66.

van Iersel, M., R.M. Seymour, M. Chappell, F. Watson, and S.K. Dove. 2009. Soil Moisture Sensor-based Irrigation Reduces Water Use and Nutrient Leaching in a Commercial Nursery. Proc. Southern Nursery Assn. Res. Conf. 54:17-21. 